\title{
La Industria del Salitre antes de la Primera Guerra Mundial. Dos Impresiones Contemporáneas sobre su Economía y Futuro
}

\author{
José Antonio González Pizarro*
}

UNIVERSIDAD CATÓLICA DEL NORTE

\section{RESUMEN}

Se examina los contenidos de dos artículos, poco conocidos, de científicos norteamericanos respecto de la industria del salitre, entre 1910 y 1913. Las publicaciones fueron abordadas desde dos ángulos diferentes y en distintas revistas. R.F. Penrose Jr, geólogo, realizó un viaje hacia las pampas salitreras de Chile, dando cuenta de los depósitos salitreros, su composición química, las vicisitudes de la guerra del Pacífico, y los procesos de transformación en las oficinas de Tarapacá, y dio a conocer sus exploraciones en una publicación de la comunidad científica; Walter Tower, geógrafo, dio una pormenorizada noticia, atendiendo a los factores sociales y económicos de los trabajadores salitreros y cómo se visualizaba el porvenir de la industria, y lo publicó en una revista de divulgación científica.

Son dos impresiones, redactadas por personas versadas en lo que escriben, y contribuyen a dar cuenta de la industria salitrera en un lapso interesante, en términos de coyuntura, pues se vive el último experimento de las combinaciones salitreras y un repunte o bonanza de la producción salitrera, traducida en la creación de nuevas oficinas salitreras y el incremento de la producción.

Palabras claves: salitre / industria / artículos /norteamericanos.

\section{Abstract}

The contents of two relatively unknown papers on the nitrate industry from 1910 to 1913, written by North American scientist, are examined. These papers are addressed from two different angles and were published in two different journals. R.F. Penrose Jr, geologist, took a trip to Chilean nitrate pampas, giving account of nitrate deposits, their chemical composition, the vicisitudes of the Pacific war, the process to change Tarapaca nitrate mines, and his explorations in a scientific journal. Walter Tower, geographer, wrote a detailed piece of news about the social and economic factors affecting nitrate workers and how the future of this industry was viewed and published it in a scientific journal.

These are two views written by experts in the area, who contribute to the dissemination of knowledge about the nitrate industry during an interesting period in terms of contingency because the last experiment of nitrate combinations is experienced, along with a rebound of nitrate production revealed by the establishment of new nitrate mines and production increase.

Keywords: nitrate / industry / papers /North Americans.

jagonzal@ucn.cl* 


\section{INTRODUCCIÓN}

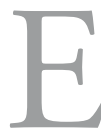

n el transcurso de la primera década del siglo XX, la industria salitrera en las provincias de Tarapacá y Antofagasta, exhibió una situación de contraste. Antes de 1907, la industria, al menos en Antofagasta, todavía no mostraba un caríz floreciente en cuanto al número de oficinas en su principal cantón, el central o boliviano, mientras se consolidaban en los cantones del Toco y Taltal, las inversiones alemanas de Henry B.Sloman y Folsch y Martin, respectivamente, y la española de Matías Granja, comenzaba su importancia en el cantón de Aguas Blancas y el puerto de Coloso. En este marco, hacía 1910 había concluido la Quinta Combinación salitrera, que había permitido fijar las cuotas de producción, para poder, en cierta forma, controlar los mercados y los precios (Brown. 1963; González Miranda, 2013)

Previamente, una investigación alemana de los ingenieros Semper y Michells, que habían recorrido el espacio salitrero en 1901, publicando sus resultados en 1904, planteaban las dificultades de la industria, en orden a cierto desgaste de los suelos nitrosos lo que, en su visión, podía apuntar a que, "el centro de gravedad de la industria irá luego avanzando hacia el Toco a medida que la pampa de Tarapacá vaya agotándose" (Semper \& Michells, 1908:174).

Para los especialistas germanos, mantener la producción del salitre a un ritmo anual de 25 millones de toneladas métricas, registrado en 1901, la industria duraría 17 años más (Semper \& Michells, 1908: 178).

Importante en este contexto, fueron tres temas que van a discurrir en la industria del salitre. La hegemonía del sistema productivo Shanks, que había introducido Santiago Humberstone en Tarapacá, después de la postguerra del Pacífico. Modelo de tecnología, de modalidad laboral y del uso de la energía.

El sistema Shanks dominó la tecnología de la lixiviación del nitrato hasta la aparición del sistema Guggenheim en 1926. Empero, desde el momento de la introducción de la nueva tecnología, se procuró en las restantes empresas salitreras y oficinas, la búsqueda de la innovación tecnológica (González Pizarro, 2016). La empresa salitrera chilena más importante, la Compañía de Salitres de Antofagasta, desde 1886 hasta su venta en 1925, no cejó en contratar 
ingenieros y técnicos que procurasen reemplazar el modelo Shanks (González Pizarro, 2017ms)

Paul Mars, últimamente, ha planteado que si bien el sistema Shanks aumentó los niveles de producción, "the system was inherently inefficient in terms of nitrate extraction from nitrate ore (caliche) and relied heavily on manual labor" (Marr, 2013: 20). Y esto era debido a la gran cantidad de mano de obra manual ocupada y las operaciones no mecánicas-desde la explosión dinamitera, el rompimiento de las piezas y la clasificación manual del mineralhasta transportar el caliche, mediante carretas tiradas por burros y/o mulas, hasta las plantas de procesamiento.

En lo que concierne a la mano de obra, el reclutamiento de los trabajadores, mediante el "enganche", un sistema de engaño empleado por los industriales para reclutar personas en el sur de Chile y en los países fronterizos de Bolivia y Perú, constituyó el principal instrumento de acrecentar la mano de obra. Dado que el nitrato de sodio era el fertilizante que reemplazó al guano, y el sistema de enganche fue el que contribuyó a transformarse al "afuerino" de las pampas en un "pampino", pues debía cancelar la deuda de su traslado y acomodo en la oficina, ha dado pie a Edward Melillo (2012), que, en esta asociación entre la industria del salitre y la primera revolución verde, no solo constituyó una intervención humana sin precedente en el ciclo global del nitrógeno, sino que vino a establecer una nueva configuración en las relaciones laborales transnacionales.

Se ha esgrimido por Melillo que esta modalidad de trabajo, que se empleó con los coolíes en la explotación del guano, planteó una realidad nueva. Se relegó a miles de trabajadores a una situación que, siguiendo a Moon-Ho Jung, fue el límite legal y cultural entre la esclavitud y la libertad, aislando a los trabajadores de paisajes familiares, mercantilizando la fuerza laboral de los trabajadores por medio de la dislocación espacial.

El trabajo de los operarios funcionaba, consignó Eugenio Frías Collao, era A trato, que involucraba a los "particulares" y "barreteros", los cuales constituían el 55\% de los trabajadores en la primera década del siglo XX. Tenían una jornada de ocho horas; Tarea, los vinculados a los trabajos de elaboración del salitre: 
chancadora, desripiamiento, canchadura, carguío de los sacos del salitre. Su jornada se extendía como promedio diez horas; Tarea mínima, que englobaba a los "carreteros", con una jornada de diez horas (Frías, 1909: 21-22).

La mano de obra contenía sus contradicciones para los empresarios, como refiere Marr (2013: 21): "Although poorly paid, the workers were skilled at their jobs and could not be replaced easily by unskilled or untrained workers".

Al momento de la redacción de los artículos de los dos científicos norteamericanos, el espacio salitrero de Tarapacá y Antofagasta estaba en expansión. Un crecimiento que venía desde el bienio 1906-1907. Las nuevas instalaciones industriales, no sólo trajo consecuencias para el comercio de ambas provincias sino el arribo de miles de enganchados, lo que se tradujo que en el censo de 1907, las regiones salitreras exhiben la mayor presencia extranjera en toda la historia nacional.

En tal sentido, cabe distinguir la coincidencia de las inversiones inglesas y alemanas con su correspondientes colonias de inmigrantes, vinculadas a la industria salitrera, a las grandes casas comerciales y a las actividades bancarias (González Pizarro, 2014; González, Lufin, Galeno, 2014), lo cual conllevó a ubicar a estas regiones en la geografía de la primera globalización mundial del liberalismo (González, Lufin, Galeno, 2016). La restante población inmigrante, era la latinoamericana, en su mayoría compuesta de bolivianos, peruanos, argentinos (González, Lufin, Galeno, 2017).

En Tarapacá, el predominio inglés era incontrastable en cuanto a influencia de capitales en el salitre, en el comercio mayorista y en su influyente colonia. La realidad demográfica latinoamericana era muy similar a la encontrada en Antofagasta (González Miranda, 2009; Tapia, 2012).

La visión sobre el salitre en 1907 de Richard A. F. Penrose JR. BREVE NOTA SOBRE EL AUTOR

Richard Alexander Fullerton Penrose Jr, se convirtió en el tiempo en uno de los geólogos más renombrados de los Estados Unidos de América. Waldemar Lindgreen, sintetizó su vida de 68 años (nació en 1863 y murió en 1931), como "Gentleman, scholar, engineer, 
benefactor" (Lindgreen, 1933). En efecto, R. A. F. Penrose Jr, como fue conocido en su trayectoria académica y profesional, además de doctorarse en Harvard University, se desempeńó como profesor de geología económica en la Universidad de Chicago (1892-1897). Trabajó para el Servicio Geológico de los Estados Unidos, donde realizó importantes investigaciones que le permitieron publicar The Nature and Origin of Deposits of Phosphate of Lime, en 1888, The Geology of the Gulf Tertiary of Texas, de 1889, Manganese, Its Uses, Ores and Deposits, en 1890, The Iron Deposits of Arkansas, en 1892 y The Last Stand of the Old Siberia en 1922 (Fairbanks \& Berkey, 1952).

Richard Penrose Jr, también se destacó como empresario minero, cuyos frutos le permitieron una fortuna de 10 millones de dólares, que distribuyó en aportes de beneficencia (fue uno de los fundadores del Hospital de Niños de Filadelfia) y legó 8 millones a la Sociedad Geológica de Estados Unidos y a la Sociedad de Filosofía Americana de Filadelfia.

Como miembro del Comité de la Sociedad Geológica sugirió en 1925 otorgar una Medalla a los más destacados geólogos, la que, finalmente, se ha conocido como Medalla Penrose (Eckel, 1982:112).

Penrose se distinguió como uno de los principales editores y patrocinadores del Journal of Geology (Chamberlain, 1931) y también como un viajero científico que recorrió casi todo el mundo y, en 1907, orientó sus pesquisas hacia América del Sur, donde la pampa salitrera de Tarapacá y Antofagasta atrajo su atención.

\section{Su artículo "The Nitrate Deposits of Chile"}

En 1910 R. A. F. Penrose Jr, dio a conocer los resultados de su viaje al norte de Chile bajo el rótulo de "The Nitrate Deposits of Chile. The Journal of Geology, vol.18, No 1, Jan-Feb, 1-32.

Penrose Jr, cubrió varios ámbitos de la industria del salitre que, para nuestro objetivo, espigaremos lo más pertinente a su situación industrial, tanto en lo productivo y el factor económico de sus transacciones y costos como a lo tecnológico, y la mirada de diagnóstico de su porvenir. Los contenidos de su artículo delataba la amplitud de temas que trató: Location of the Nitrate Regions. 
History of the Nitrate Mining Industry. Naural Features of the Nitrate Regions. Mode of Occurrence of the Nitrate Deposits in the Tarapaca Region. Materials composing the Nitrate deposits in the Tarapaca Region. Other Nitrate Regions in Chile. Origin of the Nitrate deposits of Chile. Industrial Features in the Tarapaca Nitrate Region. Nitrate deposits elsewhere than Chile.

Para este geólogo, la realidad del nitrato de Tarapacá era distinta a la de Antofagasta. La primera había comenzado con mucha antelación su explotación, por lo que era muy posible que su agotamiento fuese más temprano que el de Antofagasta. Los depósitos se ubicaban entre los $19^{\circ}$ y $26^{\circ}$ de latitud sur, donde en los últimos treinta años, había cambiado no las nomenclaturas de las regiones sino las modificaciones de la jurisdicción nacional, provocado por la guerra del Pacífico. En cuanto a las regiones salitreras, anota: "There is, however, much similarity in many of the features of the nitrate deposits in both Tarapaca and Antofagasta, though in some respects they differ considerably" (2).

Reparaba que en la industria del salitre, además de los capitales ingleses y chilenos, constataba la de los alemanes. Y esto debido a que los depósitos de nitrato, si bien menos extensos que el de las sales comunes, eran muy importantes desde el punto de vista comercial.

Le llamaba la atención que la región de Tarapacá fuese conocida como pampa "a term applied somewhat indiscriminately not only to the whole arid región, but also to special part of it, either large or small" (5).

En sus anotaciones, Penrose Jr, reparó que la mayoría de los depósitos contenían sal común (cloruro de sodio) o nitrato (nitrato de sodio), o bien mezclados ambos. Y nuevamente, subraya las designaciones del vocabulario salitrero: "The salt beds are called by the Chilean salares and the nitrate beds, salitreras. The material composing the nitrate beds is known as caliche"(9).

En su descripción de los depósitos, advierte que éstos" are usually covered by a capping composed of sand, clay, gravel, and rock fragments, from a few inches to many feet in thickness"(11).

Su descripción de las diversas capas que compone el espacio de explotación del nitrato, reconoce a la costra, reconociendo que hay una línea de demarcación en algunos lugares entre la costra y el 
nitrato. Donde se ha agotado la parte rica, se ha debido trabajar la costra. En Tarapacá, los depósitos de nitrato refieren una sucesión de formaciones:

"Chuca" (loose, wind-blown material, dust, sand, gravel, etc.)... .o-several feet

"Costra" (capping of the nitrate beds)............. 0-20 or even 30 or 40 feet

"Caliche" (crude nitrate)................................0-6 feet a few feet)

"Coba" (earthy floor of nitrate beds).......... Indefinite (perhaps

Stratified sands, clays, and gravels To great depths" (12).

El análisis químico del nitrato que trató extensamente en su artículo, fue el resultado del apoyo- y generosidad- del químico M.G.Buchanan, de la Compañía Alianza, y de J.F. Comber, gerente de la Compañía de North Lagunas. Para Penrose Jr, el panorama de la pampa de Tarapacá y Antofagasta mostraba grandes depósitos de sulfato de sodio, pero no era atractivo comercialmente. Lo mismo acontecía, de modo paradójico, con las sales de potasio cuyas existencias no eran de grandes cantidades pero serían de gran valor comercial. Sin embargo, los otros minerales pequisados no tenían la importancia del nitrato de sodio o salitre.

Si bien, en el tiempo en que viajó Penrose Jr, Tarapacá todavía mantenía el predominio de la actividad salitrera, el autor atisbó la realidad salitrera hacia el sur, la provincia de Antofagasta. Sobre ésta consignó:

"As already stated, almost all the nitrate of Chile is in the great arid basin lying between the Andes and the Coast Ranges, in the provinces of Tarapaca and Antofagasta. South of the nitrate fields of Tarapaca, already described, the main pampa region extends through the province of Antofagasta and here several large nitrate fields occur" (15).

En cuanto a los orígenes del nitrato, después de plantear las teorías que se han esbozado, siendo una de ellas la derivación a partir del guano, sintetiza:

"In concluding the subject of the origin of the nitrates and other saline deposits of the pampa, it must be said that the present discussion is intended only as a most brief and general one. A vast 
amount of geological and chemical details must be worked out both in the field and the laboratory before the subject can be fully understood. The determination of the exact conditions of deposition and the various chemical transitions through which the saline materials have gone, require far more data than are at present available." (22).

En cuanto a la minería y el procedimiento del nitrato, nos indica que se trabaja en aberturas superficiales y que la cantidad de nitrato varía en los lugares de explotación. Una página importante es la que expone el modo del trabajo en una oficina salitrera y sus posibilidades a futuro:

"In the early days, only the richest of the deposits were worked, and only crude nitrate running as high as 40 or 50 per cent. in sodium nitrate was mined, but now much lower grades are worked, and the average of the crude material used in the Tarapaca region today would run, perhaps, below 25 per cent. in nitrate... The crude nitrate is hauled in carts or on tramways from the mines to the refineries, where it is coarsely crushed and the nitrate separated from the impurities by a process of leaching with hot water. The refined product usually contains about 95 per cent. of sodium nitrate, which is the standard of purity for the nitrate shipped from the district. Sometimes a still higher-grade product is made for special purposes. The nitrate is put in large sacks, and sent to the coast for shipment to various parts of the world. Sodium nitrate is deliquescent, so that when exposed to the moist air on board ships it cakes and the sacks stick together, often forming a solid mass which has to be taken out of the ships with picks. The method used in extracting the nitrate is very crude, only from 60 to 70 per cent. of it being saved, and the average loss of nitrate in the Tarapaca region in refining is said to be about 35 per cent. Those in authority claim that under present conditions, the nitrate that is lost could not profitably be saved, but the time may come when the crude nitrate will show signs of exhaustion, and then probably less wasteful methods will be devised, and the loss will be cut down. At present, the supply of crude material is so vast that such economy has not been forced on the producers." 24 ).

Importante en su análisis, es la relación que expresa en la triada de la construcción de oficinas salitreras, la formación de pueblos y el 
papel del ferrocarril. Escribe:

"The nitrate industry is carried on largely by companies, and the establishments at which their operations are conducted are known as oficinas. Among some of the best-known oficinas in Tarapaca are the Alianza, Agua Santa, Camifia, Josefina, La Granja, Central Lagunas, North La- gunas, South Lagunas, Puntunchara, Puntilla de Huara, Rosario de Huara, Ramirez, Santa Lucia, Santiago, Uni6n, and many others. In 1907 there were almost one hundred oficinas in the Tarapaca region and about one hundred and fifty in all Chile. Many small towns have grown up on the Tarapaca Pampa as a result of the nitrate industry, among them being Dolores, Santa Catalina, Negreiros, Huara, Pozo Almonte, La Noria, Lagunas, Tapiga, San Antonio, etc."(26).

El repunte de la industria se avala en la existencia de las 150 oficinas que menciona en todo el espacio salitrero, donde Tarapacá albergaba casi 100 oficinas.

Las oficinas, las define como pequeñas comunidades que contiene grandes edificios que cobijan la administración, las casas para los empleados, tiendas, escuelas. La existencia de las oficinas no depende de los pueblos, pues en estos no necesariamente tienen oficinas.

Las principales ciudades concuerdan con los puertos salitreros. Así, en Tarapacá, Iquique, es la más importante ciudad y puerto y el centro de la actividad mercantil vinculada con el nitrato, con 50.000 habitantes, seguida de Pisagua, con 5.000 habitantes, siendo Junín y Caleta Buena los puertos menores del nitrato. En la región de Antofagasta, los puertos, sin hacer la jerarquía de las urbes, son Tocopilla, Antofagasta y Taltal.

El papel del ferrocarril queda precisado en la provincia de Tarapacá:

"The Nitrate Railways Company (an English corporation) owns a line running inland from Iquique to the Tarapaca Pampa and then branching out through the nitrate fields. It intersects the pampa from Pisaqua on the north to Lagunas on the south, a distance in a straight line of over one hundred miles and much farther as the railroad goes, besides having many lateral branches, its aggregate length being about three hundred miles. Many of the nitrate works 
located to one side or the other of the railroad are connected with it branch lines or by tramways worked by mules, and some of the nitrate companies have their own railways to the coast"(27-28).

Nuestro autor asume el papel que han tenido las Combinaciones Salitreras, con su finalidad de limitar la producción del nitrato y distribuir cuotas de producción a cada empresa anualmente. La suerte de las Combinaciones no siempre ha sido venturosa pues, varias veces se han roto por las disensiones entre los productores $y$, agrega:

"And as late as March, 1909, after it had been in force for several years, it was again broken. Recent reports, however, are to the effect that strong efforts are being made to renew it" (28).

Repara que la Combinación persigue mantener el precio del nitrato. Pero, la misma modalidad se aplica para la producción del yodo.

El juego entre el control de la producción y el precio del salitre, ha permitido acrecentar su valor por el aumento de la demanda como fertilizante. Empero, las mediciones sobre las reservas de depósitos de nitrato han sido divergentes, igual situación se aprecia sobre su porvenir. Puntualiza:

"These estimates have differed very widely, some showing that the supply would be exhausted at the present rate of consumption in twenty-five or thirty years, others that it would last for three or four hundred year. The cause of this great divergence is due to the premises on which the different estimates have been based. Many of those who predict a short life for the nitrate fields do not allow anything for future new discoveries of nitrates in northern Chile, whereas the probability of this is very great. The Chilean government owns all the nitrate deposits on the public domain and sells them only at auction. This policy has tended somewhat to retard individual effort at exploration, and hence vast regions in the Tamarugal Desert and the Desert of Atacama, which may contain nitrate, have not yet even been explored for it"(29-30).

La crítica esbozada por la injerencia gubernamental, guarda relación con su propia experiencia en los organismos gubernamentales de su país, en asuntos mineros, y su exploración como empresario minero. 
Concluye Penrose Jr, que existen en otras partes del mundo, principalmente en los Estados Unidos depósitos de nitrato de potasio, haciendo notar los esfuerzos que se están realizando para obtener nitrógeno del aire y convertirlo en nitrato u otros compuestos de nitrógeno para fines comerciales.

Y remata su extenso artículo, con la probabilidad de la transformación del nitrógeno:

"This nitrogen, as has long been known, can be oxidized by electrical and other methods and converted to nitrates and other salts of nitrogen. Numerous methods for this operation have been devised, but their discussion is beyond the scope of the present paper, and the reader is referred to the readily accessible literature on the subject for further information"(32).

\section{LA Visión SObre El SALITRE EN I9I 3 DE WALter S. Tower \\ BREVE NOTA SOBRE EL AUTOR}

Walter Sheldon Tower, fue un distinguido geógrafo norteamericano, (nació en 1881 y murió en 1969), estudió en Harvard University su master. Formó parte del grupo de académicos que estuvo ligado al Departamento de Geografía de la Universidad de Chicago, el primero en ser fundado en Norteamérica (Guide, 2017), que comenzó sus clases en el año 1902-1903. En torno a sus creadores, el geólogo Rollin Salisbury y el geógrafo Paul J. Goode, y también Harland Barrows, Ellen C. Semple, estuvo Walter S. Tower (Rucinque, 1990). También se desempeñó en la Universidad de Pennsylvania, lo cual no es extraño, pues su tesis doctoral de 1906 en esta Universidad versó sobre Regional and Economic Geography of Pennsylvania (Martin, 2015). Fue Salisbury quien le llevó a Chicago en 1910.

En su disciplina, fue autor de, A History of the American Whale Fishery, en 1907, Scientific geography: The relation of its content to its subdivisions, en 1910. Al año siguiente, de Some factors influencing the location and migration of industries. Ese mismo ańo, junto a Salisbury, Barrow, fue autor de The Elements of Geography, en 1912. Estos mismos autores, publicaron en 1913, Modern Geography for High Schools. Sus investigaciones sobre el petróleo, le permitieron escribir, junto con John Roberts, Petroleum, the Motive Power of the Future, ese mismo año, además de otros 
títulos.

Tower también se interesó en la música, publicando, entre otros libros, Fifty New Songs, en 1911.

Su colaboración en la revista Popular Science Monthly, comenzó en 1908 publicando cuatro artículo, precisamente el trabajo, que concentra nuestra atención, clausuró su relación con el mensuario. La publicación, surgida en mayo de 1872, terminó en diciembre de 1923, según Wikisource.

El estudio que publicó sobre los campos del nitrato, delata un conocimiento de primera mano de la geografía desértica y de la industria salitrera, por lo que, es posible conjeturar, que visitó la zona al despuntar la década de 1910.

Su artículo “The Nitrate Fields of Chile”

Comienza Tower su trabajo indicando que la relevancia del nitrato chileno depende de un capricho de la naturaleza pues, si bien todas las plantas y animales necesitan nitrógeno y la atmósfera también posee en cantidades nitrógeno, solo en las provincias del norte chileno se han encontrado grandes cantidades de nitrógeno.

Después de tratar la composición química y destacar los pisos de suelo que contiene el nitrato, por ejemplo, la chuca, la costra, puntualiza que el nombre de caliche es conocido el mineral que contiene el nitrato. 


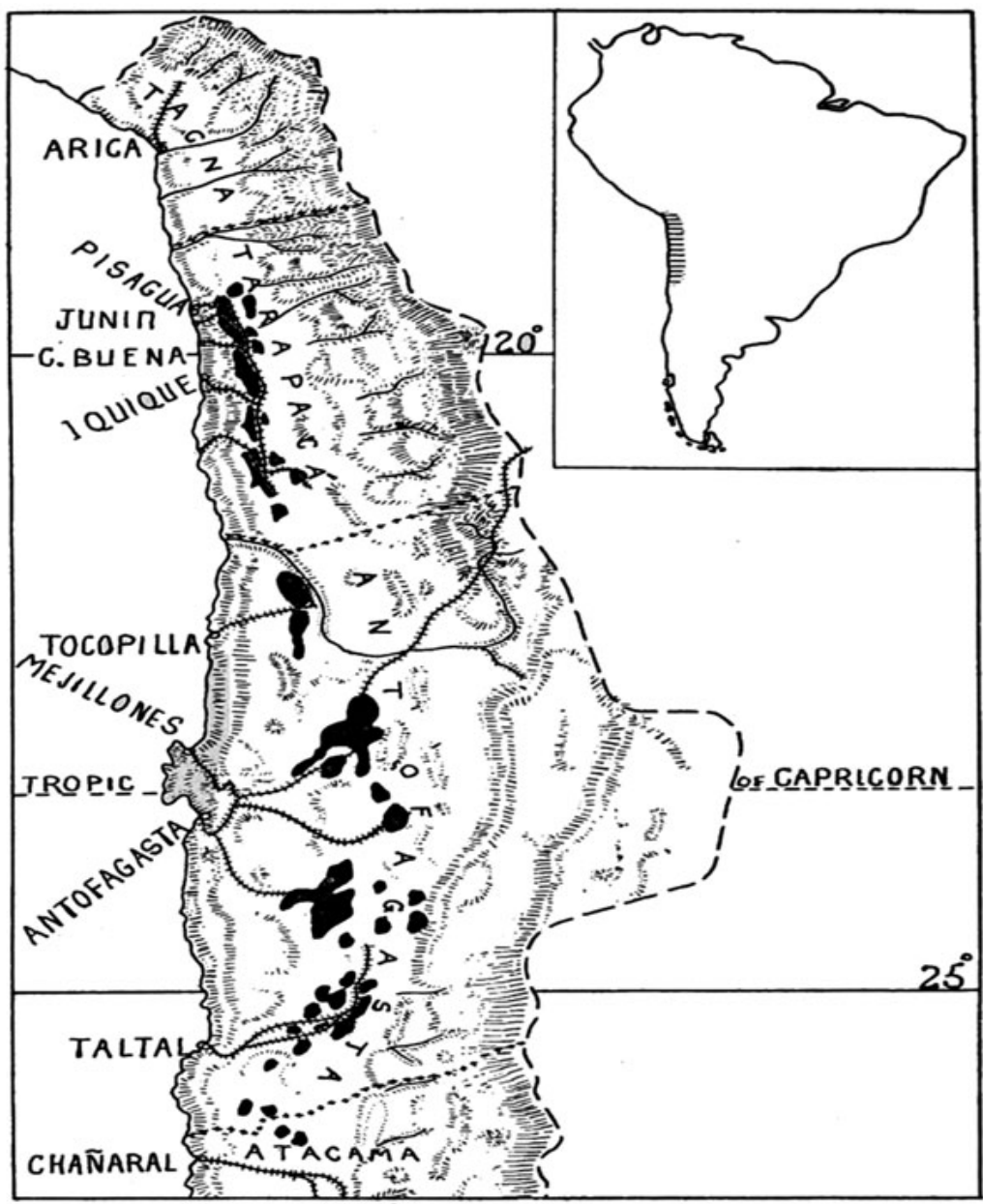

Sketch map of northern Chile, showing approximate location of nitrate lands (black areas). Cross-lined area on small map of South America shows location of nitrates province. (Tower, 1913:211).

No esquivó el asunto de los orígenes del nitrato, repasando las teorías más en boga.

Sugestivo es su planteamiento, que el recurso mencionado ha sido apreciado de modo contradictorio, como una maldición o bien como una bendición, evocando tesis muy contemporáneas sobre los recursos mineros. Escribe sobre el asunto: 
"For Chile itself no other thing has been more important than nitrate in affecting national progress. By some, nitrate has been regarded as a curse; by others, as a national blessing; and spirited arguments over its political aspects may be heard in-all parts of Chile, for the question is one of those which time does not settle. Nitrate has led to costly wars which established the prestige of Chile as the leading nation on the west coast of South America” (p.210)

Dado que el nitrato se distribuye entre Tarapacá y Antofagasta, entre los 19 y $27^{\circ}$ latitud sur, provocó el choque entre tres naciones que se vieron explotando el salitre. No solo dividió a Perú, Bolivia y Chile, sino que condujo a una guerra, donde Tower, apostilla los orígenes del conflicto del modo siguiente:

"The Chileans turned their attention largely to the Bolivian province of Antofagasta, where their influence became so marked that it is said not more than one person in twenty was a Bolivian, and that one probably an officer in the army. Important concessions were granted by Bolivia to Chilean interests, and in 1874, in return for the cancellation of a debt owed Chile, Bolivia agreed not to impose any export tax on nitrate for twenty-five years. Four years later, however, attempts were made to levy a tax of ten cents per 100 pounds on all nitrate exported. When the Chilean companies refused to pay the tax, the Bolivian authorities seized their property and declared that it would be sold. Chile was forced to step in to protect the interests of her citizens. Since Bolivia had entered some years earlier into a treaty with Peru against Chile, Peru also was dragged into the quarrel, the result of which was the beginning of war by Chile against both Peru and Bolivia in 1879 .

It was an epoch-making conflict in which Chilean naval successes against Peru were largely responsible for the outcome. The treaty of peace, signed in 1883 found Bolivia driven out of her seacoast province, Peru deprived of her nitrate lands, and the Chilean boundary pushed more than four hundred miles northward"( p.217).

Como geógrafo, es interesante ver cómo asume el espacio, desde una dimensión fenomenológica, la contradicción entre la abrupta adversidad climática del páramo y la presencia humana, perseverante, que dio lugar al pampino. Una de las páginas más hermosa escrita 
por un extranjero, la encontramos en este pasaje:

"In crossing this region one can not help feeling the utter helplessness of man in the face of such great expanses of waterless and lifeless wastes. All directions lead to sand, more sand, even to the border of the ocean itself. One fails at first to understand how men are willing to live there year after year: why those who 2:0 away generally come back again to tins apparently limitless desolation. But almost the first day's stay reveals part of the reason. The day is not unpleasant despite the heat and the intensity of the sunlight, for the extreme dryness makes temperatures of $90^{\circ}$ or more quite comfortable, and the colors-the grays, yellows, violet-playing over the sands, help make up for the lack of living green. The nights are wonderful_cool, crisp, refreshing, with the brilliancy of sky that only deserts can have; while the moonlight gleaming from millions of salt crystals lights up the land with an effect of half day and renders into attractive forms the most prosaic objects."(p. 214).

Volviendo a la industria del salitre, Tower da cuenta que los últimos quince años, ha dado cuenta de los cambios en la explotación del salitre. Por un lado, la maldición pronosticada para Chile, pues el guano y el salitre arruinaron a Perú, no se ha cumplido y, por otro, las fuertes inversiones europeas, inglesas, alemanas, francesas, austriacas, belgas, conjuntamente con las chilenas, han mejorado los métodos de explotación y la escala de operaciones se ha acrecentado. Nuevos ferrocarriles cruzan el desierto, ampliando antiguas redes ferroviarias.

Sin embargo, para el autor, lo más importante ha sido la enérgica campańa publicitaria sobre el nitrato como fertilizante, sea por medio de comités del nitrato chileno en cada región agrícola, propaganda en revistas agrícolas a nivel mundial.

Tower, relaciona el aumento de la producción con el incremento de oficinas salitreras, más de 100 están en operaciones, anota, donde varias usinas pueden producir en un mes toda la exportación que se realizó en 1830. El valor de las acciones del salitre han subido de precio. En apoyo de su aseveración, transcribe: follows:

"Thus in May, 1912, some quotations in Valparaiso were as 


\section{Name of Company}

Agua Santa

Antofagasta

Boquete

Loa

\section{Capital Paid in}

Per Share

10 pesos

25 pesos

5 pesos

1 peso

\section{Sales at}

340 pesos

180 pesos

130 pesos

67 pesos" (p.219).

No obstante, agrega el autor, que todo este crecimiento y prosperidad, no ha podido alterar el sistema de producción que sigue siendo casi el mismo de los inicios de la industria. Se comienza con un agujero de unas diez pulgadas de diámetro a través de la capa de caliche, donde se coloca la explosión de carga, el tiro de dinamita. En este escenario, entra la mayor cantidad de trabajadores del salitre, los denominados particulares. Sus condiciones demuestran la otra cara de la medalla del sistema de trabajo, como lo exhibe Tower:

"If the miner works by the day, he is known as a barretero literally a "crowbar man." If he is paid according to the amount of caliche mined, as the most energetic prefer to do, he is a particular, or private worker. The former earns about 6 pesos to 7 pesos a day, while the latter, under favorable conditions, often makes 9 pesos to 12 pesos a day. A group of particulares, working early and late, quickly dispels any idea that no people of that part of the world will work hard" (p.220).

Observa el geógrafo, esta simbiosis entre el sistema de producción y el imprescindible uso del recurso hídrico. La descripción del modelo operativo del sistema Shanks y la obtención del agua, es muy interesante:

"Carts or trains of small dumping cars carry the caliche to the maquina, as the refining plant is called. Here it is first crushed into pieces no larger than a man's fist. From the crushers it goes up inclined planes to the boiling tanks, or cachuchos as they are still known, though earthen pots have been replaced by great iron affairs 33 feet long, 9 feet wide and 8 feet deep, capable of holding 70 tons. The newest maquinas have twenty to thirty of these tanks. When the charge of caliche is in, water is added, steam is turned into a coil of pipes which runs around inside the tanks, and the boiling process 
begins to dissolve out the soluble nitrates from the insoluble and worthless earthy substances. Thus the industry, which in one respect owes its existence to absence of water, must have water in order to operate, for nowhere are there large amounts of caliche rich enough to ship without refining, and the process of leaching is the only economical method of refining.

To get water for the maquinas is not everywhere easy, for the water supply always has been the chief problem in this region. Seacoast towns for a long time depended on supplies brought by vessels from four or five hundred miles farther south. It is interesting to note here that one of the prominent figures in the development of the industry after 1880 was an English iron worker, who is said to have come out to Chile to work on the tanks or boilers of some of these water-carrying vessels, and who later went home a "nitrate millionaire." The first railroads had trouble getting water for their engines, some resorting to the distillation of salt water, but now, for the railroads and the chief cities and towns, piping of water 100 to 200 miles from the Andine streams has relieved the situation greatly. Water, however, still must be used sparingly and almost everywhere the poorer people buy it by the pailful, a discarded kerosene tin generally serving as a pail. A common price is 10 centavos $(=3$ cents) for five gallons. In the pampa, wells yield a good deal of water, commonly more or less salty, but this source can not be counted on everywhere. Thus in central Antofagasta one plant secures more than 35,000 gallons of water daily from three wells, the deepest of which is less than 100 feet, but another plant, less than a mile away, found no underground water after spending 250,000 pesos in the attempt" (p.221)

En su descripción de la industria del nitrato, Tower consignó que, en la actualidad, se necesitaba mayores inversiones para introducirse en el negocio salitrero. Muchas de las oficinas más antiguas, son pequeñas, lo que se traducía en una inversión menor entre 25 y 50.000 pesos. En 1913, una gran planta requiere un capital de 6 millones de pesos. Esto reflejaba dos realidades: de un total de 160 oficinas existentes, no todas estaban operativas, siendo el agotamiento del caliche la razón más común. Unas 80 oficinas permanecían en manos de empresas, siendo las más grandes las 
dominantes de la industria. Llamaba la atención, del interés de los capitales norteamericanos en la industria, aunque cuando constataba que éstos eran atraídos en América del Sur por otro tipo de minería.

Dentro de los capitales chilenos, se destacaba la moderna oficina Aníbal Pinto. La atención que le prestó a ésta, le permite introducirse en la variedad de insumos importados que requiere la instalación de una moderna usina. Este primer acercamiento, de carácter industrial y bursátil, veremos después, va a dar lugar, al contraste del mundo obrero. Veamos las pinceladas con que celebra a la oficina Aníbal Pinto:

"A modern oficina, like the Aníbal Pinto, in central Antofagasta, running twenty-four hours at full capacity, may have a daily output of 5,000 Spanish quintals (quintal $=101$ pounds) of nitrate. The cost of production in May, 1912, at this plant, was stated to be about 2.50 pesos per quintal, covering everything up to the time of shipment. To this figure must be added the transportation charges to the vessel in Antofagasta harbor, about 1 peso per quintal, and the export duty of 2.50 pesos per quintal, making total costs on board vessel 6 pesos per quintal. At that time the selling price, on hoard ship, was 7.50 pesos to 8 pesos per quintal. Under favorable conditions, therefore, this oficina could market about 2,000,000 quintals a year, with profits amounting to $4,000,000$ pesos. This particular oficina cost more than $6,000,000$ pesos, but with the trade good, it would pay for itself in two years and give annual dividends of. 10 per cent, at the same time. About five and a half square miles of nitrate lands have been set aside for the Pinto, a supply calculated to keep it going for twenty years, in most of which time the plant has nothing to do except pay dividends. The making of nitrate millionaires, therefore, is easy to understand.

The construction of a modern oficina uses supplies from widely separated places. Most of the buildings are of corrugated iron, for it withstands the intense darkness better than wood does. It commonly comes from Europe. The timber which is used is likely to be Oregon pine, for it is strong, durable and about as cheap as the Chilean product. German steel for tanks, cement from the United States, boilers from England, Belgian locomotives to haul the tiny cars and United States electrical equipment are found at one oficina”.(p.225). 
El panorama laboral, plantea una sociedad transnacional en la oficina salitrera, donde la migración se hace presente con los operarios bolivianos y peruanos y con el contingente chileno; todos enganchados. Se hace cargo de las denuncias respecto de los empresarios salitreros, que han retrasado la modernización de la agricultura no solo por distraer los capitales hacia la minería del norte sino por absorber la mano de obra agrícola, principalmente por el ofrecimiento del enganchador, de ofrecer altos salarios en un mundo donde las especies y no la moneda corriente constituía el salario cotidiano.

Importante, es la comparación que realiza entre las remuneraciones que percibe el obrero salitrero, y los profesionales y administrativos de una oficina, y de qué manera ese poder adquisitivo se traduce en la capacidad de compra de elementos vitales. No deja de sorprenderse del monopolio que ejerce la pulpería en el entramado de una oficina salitrera. Y del uso de la ficha salitrera. Es un friso muy relevante en cuanto a la descripción de la vida cotidiana:

"Wages run from about 3 pesos to 4 pesos per day for boys and 6 pesos per day for the poorest paid men. up to as high as 15 pesos for some of the men working in the maquina. Perhaps 10 pesos is a fair average for the majority. Houses are provided by the company, but heat, light and water must be paid for by all except salaried employes. This latter class, including the manager, or administrador, and his subordinates, the engineer, bookkeeper, chemist, electrical expert, etc., are given their quarters, heat, light and water, in addition to salaries that range from 1,000 pesos up to 4,000 pesos a month.

Though wages and salaries appear high in units of currency, the prices of food stuffs also are necessarily high, since next to nothing can be raised anywhere in the nitrate region. Some prices charged in company stores are as follows: flour, 20 pesos per quintal; beans, 30 pesos per sack of about one bushel; eggs, 6 pesos a dozen; coal, $\mathrm{G}$ pesos for about 100 pounds. Only canned milk can be had, for there is no way of keeping cattle in this barren land. All cuts of meat are 50 cents per pound, and the rule of "first come, first choice" results in the formation of a "meat line" early every morning. A good many of the cattle used here come overland from Argentina. Kerosene from the United States costs about 1 peso a gallon, but 
the tin in which it comes also must be considered, since it serves a multitude of uses from waterpail to roofing material and baking oven. Potatoes are commonly sold by the half robo, which equals about a half bushel, but the natives are fond of explaining, with a significant gesture, that robo also means robbery.

The laborers generally are paid not in money, but in features, discs resembling poker chips and bearing the company name, together with the equivalent value in actual currency. These features are used almost solely at the company stores, but if any workman desires his wages in money he may draw at any time all that is due him. For the salaried employees, the pampa looks like a good place to save money, since food is about the only thing he cares to buy in the local stores. Some of the larger coast towns have fairly good stores, but Valparaiso is the nearest real "spending place," and to get there takes four days to a week. The mail-order business, however, is said to thrive here mainly because of these very conditions, with disastrous results to the saving habit" (p.226-227).

La oficina salitrera tiene vida propia en la onhóspita pampa salitrera. Cada una de ellas, puntualiza Tower, comprende una comunidad entre 2 a 3.000 personas. En su interior alberga escuelas, sostenidas por el gobierno, siendo sus preceptores remunerados por el estado y complementadas sus remuneraciones por las compañías salitreras. Se les entrega habitaciones con las comodidades, de calefacción y agua. Tienen clubes musicales y sociales. Se escucha música al aire libre, aunque su sonido no es el más armónico, "and worse music may be heard in many more favored parts of the world". El fútbol es el deporte favorito y las competencias se realizan con otras oficinas cercanas. Otras amenidades adornan a la oficina salitrera:

"There is the inevitable biograph, a dance hall, annual visits by a circus, a saloon and even a gambling house, for since the men will gamble anyway, it is deemed best to have it done where some control may be exerted over it. Little trouble ever arises, for the resident manager is in some ways a local czar, with the very efficient mounted police of the pampa to assist in keeping order."(p.227).

Empero, Tower se plantea la dicotomía del mundo obrero que observa y que le relatan. Afirma: 
"It is sometimes claimed that the laborers are exploited outrageously by the companies; that two prices are the rule in the company stores, the higher price always being for the laborers; that buying outside is almost or quite impossible; that they are assessed for medical service which they never need, and so on. It is also pointed out that although provided with houses, the living conditions among the laborers are decidedly primitive, especially as regards sanitary arrangements. It is quite true that the camp commonly is placed where the wind will not carry the odors to the houses occupied by the manager and his subordinates. But in the bright sun and dry air of the desert, most disease germs do not thrive, and there filth, unpleasant as it may be, does not lead to the sickness which it might cause elsewhere. In order to get some return from the monthly assessment of a peso for doctor's services, so it is said, the people commonly feign illness, until the free medicine is received, whereupon the medicine promptly is thrown away. There probably is some truth in all the claims that the lot of the nitrate workers is not everything which could be desired, yet it is undeniable that they are better off than a good many of their own countrymen who are working elsewhere" (p.228).

La descripción de la pampa salitrera, con todas sus contradicciones, logra transmitir la racionalidad de los negocios con el sentimiento que abriga su contingente humano. Esta imagen no se replica en el borde costero:

"Living in the nitrate pampa has some compensations, as in the feelings inspired by the desert and especially in the beauty of its nights, but not even the mighty Pacific can lend charm to the seaports which act as middlemen between the oficinas and the outside world" (p.228).

Los puertos de Iquique, Antofagasta, Taltal, Chañaral (¿?), Mejillones, Pisagua y Tocopilla, revelan las etapas tempranas de la evolución de las ciudades mineras del oeste norteamericano, con una tediosa monotonía. Incluso los extranjeros, disfrutando del mar y las playas, se refugian en el alcohol para variar su existencia. Las ciudades no poseen buenos puertos, por lo que los buques deben anclarse lejos. Las urbes son amorfas, calles anchas sin pavimentar, polvorientas. La plaza, con sus pocos árboles, no logra trastocar 
una impresión de abatimiento. Los hoteles sucios llenos de clientes de diversas nacionalidades, deja una impronta cosmopolita. Una distracción es ver los muelles repletos de pasajeros y las focas. Pero es un instante. La escapatoria del viajero en una urbe nortina, en espera del barco, es haber permanecido en la pampa, "where the world seems big and less forlorn"(p.229).

Tower, examina la contribución del salitre al erario fiscal, anotando que el $70 \%$ del valor total de las exportaciones proviene del nitrato. Los derechos del salitre y el producto de las ventas de tierras del nitrato ha permitido fluctuar los ingresos fiscales desde un 50 a no menos un 85\%. Esto es, apostilla Tower, lo que ha dejado impresiones contradictorias sobre lo que hace Chile con tales ingresos:

"These revenues alone represent more than ten dollars per capita or as much as the United States government spends from all sources of income. It is easy to see, therefore, why Chile often is charged with extravagance. Yet large sums have been employed wisely in the building of state railroads; something has been done, and imich more is now being undertaken, to improve port facilities, especially at Valparaiso; and much of the money has been used in building up an army and navy to insure Chilean leadership and prestige among the West Coast countries" (p.229-230).

Nuestro autor, justiprecia el rol de las Combinaciones Salitreras en el control de la producción de las grandes empresas, funcionando la confianza pero, desde 1909, muchas empresas han limitado su producción solo por la capacidad máxima de sus instalaciones industriales.

Tower examinando las cifras de producción y las estimaciones de las reservas, considera que hay factores que inciden en éstas. Por un lado, la apertura del Canal de Panamá, va a reducir los costos de transporte para el abastecimiento desde Iquique y Antofagasta hacia los Estados Unidos, Reino Unido y Alemania, que son los países que concentran el $80 \%$ de las exportaciones del nitrato. Por otro, se considera que la producción actual anual podría asegurar una vida al salitre por 35-40 años y los depósitos actuales son menores y no hay mejoras en los procesos de producción.

Al igual que Penrose Jr, Tower advierte de los ensayos que se 
están llevando a cabo en Noruega de la producción de nitratos a partir del nitrógeno atmosférico:

"Another possible " rock ahead " for the business has been found by some people in the production of nitrates from atmospheric nitrogen by an electrical process. Where water power is abundant and cheap, nitrates from this process can be made to compete with the Chilean product. It is being done now in Norway. But for most parts of the world which have large water-power resources the use of this power will be more valuable for other purposes as long as Cliilean nitrates continue to be abundant and reasonably cheap" (p.231).

Tower, afirma rotundamente, que cuando se agote el nitrato, las pérdidas para Chile serán cuantiosas. La pampa salitrera podría convertirse en una región altamente agrícola mediante el riego, por lo menos en áreas limitadas. El mundo va a requerir de otra fuente de nitrógeno para fertilizar sus cultivos: "Happily the way already is open for the latter change".

Efectivamente, la Primera Guerra Mundial abrió las puertas al salitre sintético, que fue la competencia del salitre natural en el mercado de los fertilizantes.

\section{Conclusiones}

Los dos textos comentados de Richard Penrose Jr. Y de Walter Tower, son relevantes por varios motivos. Uno, por su capacidad profesional en sus campos disciplinares: la geología y la geografía, descollando ambos en el mundo de la investigación universitaria y de campo. Dos, los análisis complementarios que llevan a cabo, permiten contar con dos informes publicados, poco conocidos, sobre la situación de la industria salitrera y cómo visualizan los desafíos que afronta este rubro minero, en cuanto a la falta de innovación tecnológica, poca incorporación de nuevas áreas de explotación calichera, la inconformidad del mundo obrero con sus condiciones de vida, a pesar que son muy superiores a otras partes de Chile. Tres, el poco progreso que exhiben las ciudades puertos del salitre considerando la cuantiosa contribución al erario nacional, no solo en infraestructura sino en el avance de su fisonomía urbana. Cuarto, la despreocupación del estado nacional por la investigación 
científica aplicada a la producción del nitrato, máxime cuando el recurso constituye el principal aporte al presupuesto nacional.

Los textos informan de una realidad que asombra por su capacidad analítica técnica y social y, abren, un cuestionamiento al mundo cientifico y profesional nacional contemporáneo en esta materia.

BibLIOGRAFíA

BROWN, J.R. 1963. Nitrate Crisis, Combinations and the Chilean government in the Nitrate Age, The Hispanic American Historical Review. 43, May, 230-246.

CHAMBERLAIN, ROLLIN T. 1931. "Richard Alexander Fullerton Penrose Jr. 1863-1931", The Journal of Geology, vol.39, Number 8, Nov-Dec.

FAIRBANKS, HELEN R. AND CHARLES P. BERKEY.1952.

Life and Letters of R. A. F. Penrose, Jr. (New York: Geological Society of America.

FRÍAS COLLAO, EUGENIO. 1909. El trabajo en la industria salitrera. Informes presentados a la oficina de Estadística del Trabajo. Santiago de Chile, Imprenta Cervantes.

GONZÁLEZ MIRANDA, SERGIO.2009. La presencia boliviana en la sociedad del salitre y la nueva definición de la frontera: auge y caída de una dinámica transfronteriza (Tarapacá 18801930). Chungará, junio, vol.41, No 1, 71-81.

GONZÁLEZ MIRANDA, SERGIO. 2013. Las combinaciones salitreras: el surgimiento del empresariado del nitrato en Chile (1884-1910), Diálogo Andino. Revista de Historia, Geografía y Cultura Andina, No42, diciembre, 41-56.

GONZÁLEZ, JOSÉ ANTONIO; LUFIN, MARCELO Y CLAUDIO GALENO, "Británicos en la región de Antofagasta. Los negocios concomitantes con la minería del desierto de Atacama y sus redes sociales (1880-1930)". Estudios Atacameños. $\mathrm{N}^{\circ}$ 48. 2014. pp. 175-190.

GONZÁLEZ, JOSÉ ANTONIO, GALENO, CLAUDIO Y MARCELO LUFIN, "Antofagasta, a city in the Ata- cama Desert. Immigration, globalization, and nitrate industry: 1880-1930". The Global City: Past and Present. Institute for 
Historical Research. London. May 26-27. 2016.

GONZÁLEZ PIZARRO, JOSÉ ANTONIO, LUFIN VARAS, MARCELO AND GALENO IBACETA, CLAUDIO.2017. Mujeres latinoamericanas en el mercado laboral de Antofagasta durante el ciclo salitrero, 1880-1930. Estudios Atacameños, No 54, 153-178.

GONZÁLEZ PIZARRO, JOSÉANTONIO.2014.La inmigración europea en Antofagasta y su influencia comercial durante el ciclo salitrero 1880-1910. En Ladino Tapia, Marcela-González Gil Adriana (Editoras), Regiones Fronterizas, Migración y los desafíos para los estados nacionales latinoamericanos. Santiago. Ril Editores-Unap, pp. 335-359.

GONZÁLEZ PIZARRO, JOSÉ ANTONIO. 2017. La épica del salitre en el desierto de Atacama entre 1880-1967.Trabajo, tecnologías, vida cotidiana, conflicto y cultura. Ediciones Universitarias, Universidad Católica del Norte.

GONZÁLEZ PIZARRO, 2017.Ms. La Compañía de Salitres de Antofagasta. De la modernización empresarial a la innovación estratégica: los años de desafíos 1916-1925. Estudios Atacameños. En vías de publicación.

GUIDE TO THE UNIVERSITY OF CHICAGO DEPARTMENT OF GEOGRAPHY RECORDS 19021975. Disponible en: https://www.lib.uchicago.edu/e/scrc/.../ view.php?... GEOGRAPHY Consulta 17 de noviembre de 2017.

LINDGREN, WALDEMAR.1933. "Memorial of Richard Alexander Fullerton Penrose Jr. December 17, 1863-July 31, 1931. A Tribute to His Life and Achievements", Proceedings of the American Philosophical Society, Vol.72, $\mathrm{N}^{\circ} 3$.

MARR, PAUL. 2013. Technology, labor, and the collapse of Chile's Nitrate Industry. Middle States Geographer, 46: 19-26.

MARTIN, GEOFFREY J. 2015. American Geography and Geographers Toward Geographical Science. N.Y: Oxford University Press.

MELILLO, EDWARD. 2012. The First Green Revolution: Debt Peonage and the Making of the Nitrogen Fertilizer Trade, 1840-1930. The American Historical Review, Vol.117, Issue 
4, October, 1028-1060.

PENROSE JR. R.F.1910. The Nitrate Deposits of Chile. The Journal of Geology, vol.18, No 1, Jan-Feb, 1-32.

RUCINQUE, HÉCTOR F. 1990. Carl Sauer: Geógrafo y maestro par excellence. Trimestre Geográfico, N 14, mayo, 3-19.

SEMPER, DR - DR. MICHELLS, 1908. La industria del salitre en Chile....traducida directamente del alemán y considerablemente aumentada por Javier Gandarillas y Orlando Gigliotto Salas, Santiago de Chile: Imprenta Litografía y Encuadernación Barcelona.

TAPIA LADINO, MARCELA.2012. Frontera y migración en el norte de a partir del análisis de los censos población: Siglos XIX- XXI. Revista de Geografía Norte Grande. Diciembre, no. 53, p.177-198.

TOWER, WALTER. 1913. The Nitrate Fields of Chile. The Popular Science Monthly, september, vol.83, 209-230

Fecha de Recepción del Artículo: 10 de septiembre de 2017 Fecha de Aceptación: 10 de octubre de 2017 